\title{
High-Density Lipoprotein Subclass Distribution And Human Cord Blood Lipid Levels
}

\author{
ORSOLYA GENZEL-BOROVICZENY, TRUDY M. FORTE, AND MELISSA A. AUSTIN
}

Donner Laboratory, Lawrence Berkeley Laboratory, University of California, Berkeley, California 94720

\begin{abstract}
The high-density lipoprotein (HDL) subclass distribution was examined by gradient gel electrophoresis (gge) in 154 human cord blood samples, and determinations of triglyceride, total cholesterol, and HDL-cholesterol levels were performed. Three distinct gge patterns were recognizable. The first pattern, termed the normal (gge) pattern, was distinguished by a prominent double peak in the $\left(\mathrm{HDL}_{2 \mathrm{a}}\right)_{\mathrm{gge}}$ region and a pronounced peak in the $\left(\mathrm{HDL}_{3 \mathrm{~b}}\right)_{\mathrm{gge}}$ region. Minor peaks, or shoulders, were also seen in the $\left(\mathrm{HDL}_{2 b}\right)_{\mathrm{gge}}$ and $\left(\mathrm{HDL}_{3 c}\right)_{\mathrm{gge}}$ regions, and a valley was present in the $\left(\mathrm{HDL}_{3 \mathrm{a}}\right)_{\mathrm{gge}}$ region. This pattern was associated with normal lipid levels for cord blood plasma (mean triglycerides: $30-42 \mathrm{mg} / \mathrm{dl}$; mean total cholesterol 62-85 mg/dl; mean HDL-cholesterol: 34-41 mg/ dl). The second pattern, termed the $2 \mathrm{~b}$ (gge) pattern, contained a major peak in the $\left(\mathrm{HDL}_{2 \mathrm{~b}}\right)_{\mathrm{gge}}$ region rather than the shoulder seen in the normal (gge) pattern, while the $\left(\mathrm{HDL}_{2 \mathrm{a}}\right)_{\mathrm{gge}},\left(\mathrm{HDL}_{3 \mathrm{~b}}\right)_{\mathrm{gge}}$, and $\left(\mathrm{HDL}_{3 \mathrm{c}}\right)_{\mathrm{gge}}$ regions were less pronounced. This pattern was associated with elevated total cholesterol and HDL-C levels (means 85-102 and 49-56 $\mathrm{mg} / \mathrm{dl}$, respectively). The third pattern, termed the $3 \mathrm{~b}$ (gge) pattern, was characterized by a paucity of material in the $\left(\mathrm{HDL}_{2 b}\right)_{\mathrm{gge}}$ region, a single peak in the $\left(\mathrm{HDL}_{2 \mathrm{a}}\right)_{\mathrm{gge}}$ region, and either a relative increase in the $\left(\mathrm{HDL}_{3 b}\right)_{\mathrm{gge}}$ region, or a simultaneous increase in both $\left(\mathrm{HDL}_{3 b}\right)_{\mathrm{gge}}$ and $\left(\mathrm{HDL}_{3 \mathrm{c}}\right)_{\mathrm{gge}}$. This pattern was associated with elevated triglyceride levels (means $78-88 \mathrm{mg} / \mathrm{dl}$ ) and decreased HDL-C levels (means 20-30 mg/dl). Only two infants had a simultaneous elevation of triglycerides and total cholesterol and both cases exhibited the $3 \mathrm{~b}$ (gge) pattern. Our study demonstrates that although the triglyceride and cholesterol levels in the newborn are much lower than those in adults, they are the important factors associated with the HDL subclass distribution. Elevated cholesterol was related to increased particles in the $\left(\mathrm{HDL}_{2 \mathrm{~b}}\right)_{\mathrm{gge}}$ region while elevated triglyceride levels were associated with a decrease in $\left(\mathrm{HDL}_{2 \mathrm{~b}+2 \mathrm{a}}\right)_{\mathrm{gge}}$ particles and a concomitant increase in $\left(\mathrm{HDL}_{3 \mathrm{~b}}\right)_{\mathrm{gge}}$ particles. (Pediatr Res 20: 487-491, 1986)
\end{abstract}

Abbreviations

HDL, high-density lipoproteins

TG, triglyceride

TC, total cholesterol

HDL-C, HDL-cholesterol

gge, gradient gel electrophoresis

CB, cord blood

Received October 7, 1985; accepted January 23, 1986.

Address correspondence and requests for reprints to Orsolya Genzel-Boroviczeny, M.D., Donner Laboratory, 1-213, University of California, Berkeley, CA 94720 .

This work was supported by NIH Program Project Grant HL 18574 from the National Heart, Lung, and Blood Institute of the National Institutes of Health and NIH National Research Service Award Training Grant HL 07279.
There is growing evidence that HDL, and in particular the $\mathrm{HDL}_{2}$ subclass, have a protective role in the process of atherogenesis (1-3). In contrast to adults, in whom low density lipoproteins predominate, HDL is the predominant lipoprotein species in human CB (4-10). Davis et al. (4) found that in healthy term infants with lipoprotein levels below $100 \mathrm{mg} / \mathrm{dl}$, cord blood HDL differed from that of adult in size distribution and in apolipoprotein content. They noted that the less dense HDL components of $\mathrm{CB}$ were larger, enriched in unesterified cholesterol, and contained the bulk of apolipoprotein E; the latter was principally in the apolipoprotein (E-AII) complex form. The more dense HDL components were smaller and enriched in total protein and cholesteryl ester. Evaluation of HDL particle size distribution by gradient gel electrophoresis revealed that the CB HDL distribution was broader than that reported for adult HDL by Blanche el at. (11) and was deficient in $\left(\mathrm{HDL}_{3 \mathrm{a}}\right)_{\mathrm{gge}}$, the major peak in adult HDL. Several reports indicate that prematurity and pre- and perinatal complications elevate the cholesterol and TG levels of cord blood (12-22). However, little is known about the effect of elevated lipid levels on the HDL subclass distribution in the newborn. The purpose of this study is to evaluate the relationship between the HDL particle size distribution and levels of cholesterol and TG in CB.

\section{MATERIALS AND METHODS}

Cord blood samples. Umbilical CB was collected into tubes containing EDTA $(1 \mathrm{mg} / \mathrm{ml})$ and refrigerated immediately. Red cells were separated from plasma by centrifugation at $4000 \times g$ for $20 \mathrm{~min}$ at $4^{\circ} \mathrm{C}$. TC and TG were quantitated on $880 \mathrm{CB}$ samples over an 8-month period. Of the total $\mathrm{CB}$ plasmas examined, 154 samples with plasma volume of $2 \mathrm{ml}$ or more were selected for determination of HDL-cholesterol and for evaluation by gradient polyacrylamide gel electrophoresis. Since prematurity and perinatal complications have been shown to be associated with elevated CB lipid levels (12-22), emphasis was placed on inclusion of infants with pre- and perinatal complications or lipid levels above $100 \mathrm{mg} / \mathrm{dl}$.

Determination of the lipid levels. Total plasma TG and cholesterol values were determined by means of enzymatic kits (TG with kits from Gilford Diagnostics, Cleveland, OH; TC with kits from Worthington Diagnostics, Freehold, NJ). Assays require a total of $0.1 \mathrm{ml} \mathrm{CB}$ plasma. HDL-C was determined by the precipitation technique of Steele et al. (23). Briefly, heparin and $\mathrm{MnCL}_{2}$ were added to $0.5 \mathrm{ml}$ plasma and incubated for $30 \mathrm{~min}$. After incubation, the samples were centrifuged for $30 \mathrm{~min}(1500$ $\times g$ at $4^{\circ} \mathrm{C}$ ) and the supernatant pipetted. The supernatant was then analyzed for cholesterol (= HDL-C).

Lipoprotein isolation and gradient gel electrophoresis. CB lipoproteins were isolated at $\mathrm{d} 1.21 \mathrm{~g} / \mathrm{ml}$ in a single ultracentrifugal step in a Beckman 40.3 rotor $\left(100,000 \times g 24 \mathrm{~h}\right.$ at $\left.4^{\circ} \mathrm{C}\right)$ essentially as described by Lindgren et al. (24). To isolate lipoproteins, $2 \mathrm{ml}$ of cord plasma were underlaid with $4 \mathrm{ml}$ of $\mathrm{NaCl}-\mathrm{NaBr}$ of $\mathrm{d}$ 1.310 ; cord plasmas with volumes of $1.5 \mathrm{ml}$ were adjusted to 2.0 $\mathrm{ml}$ with $0.154 \mathrm{M} \mathrm{NaCl}$ prior to centrifugation. After centrifugation, the top $1.0 \mathrm{ml}$ of $\mathrm{d} \leq 1.21 \mathrm{~g} / \mathrm{ml}$ was harvested by pipetting. 
The $\mathrm{d}<1.21 \mathrm{~g} / \mathrm{ml}$ fractions were analyzed by gradient polyacrylamide gel electrophoresis in order to determine HDL size distribution. This is a nondenaturing electrophoretic analysis that shows good reproducibility of particle size; the coefficient of variation with $4-30 \%$ gels is $0.5-1.7 \%(25)$. Total pattern area and the relative distribution of area among the subpopulations is reproducible, on average, to within $10 \%$. Electrophoresis was carried out on precast Pharmacia $4-30 \%$ polyacrylamide slab gels (Pharmacia, Piscataway, NJ) according to the procedure of Nichols et al. (25). Reference proteins used to determine particle diameter consisted of thyroglobulin, apoferritin, lactate dehydrogenase, and bovine serum albumin. Gels were stained with Coomassie G-250 to identify protein bands, and densitometric scans were obtained with a Transidyne RFT densitometer (Transidyne Corp., Ann Arbor, MI).

To compare the HDL particle size distribution of individual CB lipoprotein samples, the $\mathrm{d}<1.21 \mathrm{~g} / \mathrm{ml}$ fractions were electrophoresed on $4-30 \%$ gels and were then scanned after protein staining. As illustrated in Figure 1, the height (in $\mathrm{cm}$ ) of each peak and shoulder was measured and its relative value calculated as a percentage of the total of all heights in the scan. This value is then the relative optical density of that particular protein band. If no peak or shoulder was present, the relative optical density was considered to be 0 . The terms $\left(\mathrm{HDL}_{3 \mathrm{a}}\right)_{\mathrm{gge}}$, $\left(\mathrm{HDL}_{3 \mathrm{~b}}\right)_{\mathrm{gge}}$, and $\left(\mathrm{HDL}_{3 c}\right)_{\mathrm{gge}}$, according to the nomenclature of Nichols et al. (25), designate major particle size subpopulations observed by gradient gel electrophoresis within the ultracentrifugal $\mathrm{HDL}_{3}$ fraction $(\mathrm{d}$

$\begin{array}{ccccc}\text { PEAK } & R_{f} & \begin{array}{c}\text { DIAM } \\ (\mathrm{nm})\end{array} & \begin{array}{l}\text { O.D. } \\ (\mathrm{cm})\end{array} & \begin{array}{r}\text { relative O.D. } \\ (\%)\end{array}\end{array}$

\begin{tabular}{ccccc}
\hline $\mathrm{b}$ & 0.514 & 11.2 & 1.8 & 13 \\
$2 \mathrm{a}_{1}$ & 0.645 & 9.4 & 3.6 & 25 \\
$2 \mathrm{a}_{2}$ & 0.696 & 8.9 & 3.7 & 26 \\
$3 \mathrm{~b}$ & 0.818 & 7.9 & 3.2 & 23 \\
$3 \mathrm{c}$ & 0.911 & 7.4 & 1.8 & 13
\end{tabular}

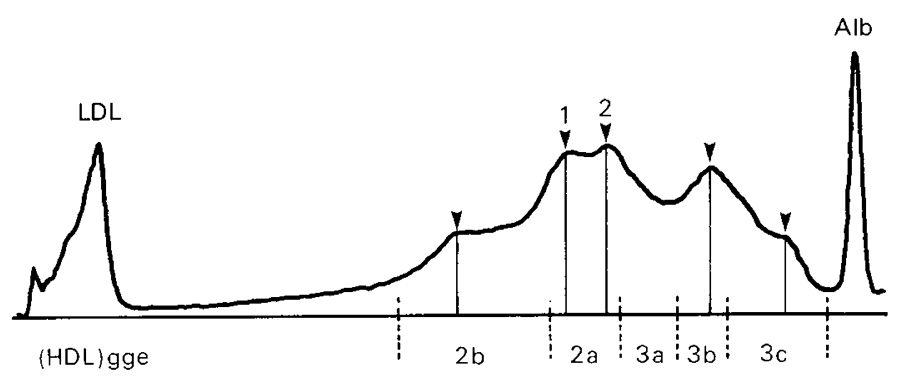

Fig. 1. A representative gradient polyacrylamide gel electrophoresis scan pattern of the plasma $\mathrm{d}<1.21 \mathrm{~g} / \mathrm{ml}$ fraction of a normal term infant (TG, $49.1 \mathrm{mg} / \mathrm{dl}$; TC, $63.8 \mathrm{mg} / \mathrm{dl}$ ) on a $4-30 \%$ gel demonstrating how the scans were quantitatively evaluated. The HDL peaks and shoulders are indicated by arrows; the two peaks under $\left(\mathrm{HDL}_{2 \mathrm{a}}\right)_{\mathrm{gge}}$ are designated $l$ and 2 . The designations of (HDL) gge are described in "Materials and Methods" and in References 11 and 25. The optical density $(O . D$.) is measured as peak height in $\mathrm{cm}$ (vertical lines) and then converted to relative optical density $(\%)$ for each peak. $\mathrm{R}_{\mathrm{f}}$ values and corresponding particle size (diameter in $\mathrm{nm}$ ), absolute and relative optical density for the five peaks are shown in tabular form. The relative optical density values are used to compare particle size distribution among individual cord blood samples. The low-density lipoprotein $(L D L)$ region, as indicated, forms a sharp peak in the left side of the scan while albumin $(a l b)$ forms a sharp peak at the right side.
$1.125-1.20 \mathrm{~g} / \mathrm{ml})$ from adult plasma, while the terms $\left(\mathrm{HDL}_{2 \mathrm{~b}}\right)_{\mathrm{gge}}$ and $\left(\mathrm{HDL}_{2 \mathrm{a}}\right)_{\mathrm{gge}}$ designate $\mathrm{HDL}$ subpopulations within the $\mathrm{HDL}_{2}$ (d $1.063-1.125 \mathrm{~g} / \mathrm{ml}$ ) ultracentrifugal fraction. Particle size intervals defining these subpopulations are $\left(\mathrm{HDL}_{2 \mathrm{~b}}\right)_{\mathrm{gge}}, 12.9-9.7$ $\mathrm{nm} ;\left(\mathrm{HDL}_{2 \mathrm{a}}\right)_{\mathrm{gge}} 9.7-8.8 \mathrm{~nm} ;\left(\mathrm{HDL}_{3 \mathrm{a}}\right)_{\mathrm{gge}}$ 8.8-8.2 nm; (HDL $\left.{ }_{3 \mathrm{~b}}\right)_{\mathrm{gge}}$, 8.2-7.8 $\mathrm{nm}$; and $\left(\mathrm{HDL}_{3 \mathrm{c}}\right)_{\mathrm{gge}}, 7.8-7.2 \mathrm{~nm}$ (25). Unlike adult plasma HDL, CB HDL contained two distinct peaks within the $\left(\mathrm{HDL}_{2 \mathrm{a}}\right)_{\mathrm{gge}}$ interval and often within the $\left(\mathrm{HDL}_{3 \mathrm{c}}\right)_{\mathrm{gge}}$ region as well. The double peaks in the $\left(\mathrm{HDL}_{2 \mathrm{a}}\right)_{\mathrm{gge}}$ and $\left(\mathrm{HDL}_{3 \mathrm{c}}\right)_{\mathrm{gge}}$ were designated $\left(\mathrm{HDL}_{2 \mathrm{a} 1}\right)_{\mathrm{gge}},\left(\mathrm{HDL}_{2 \mathrm{a} 2}\right)_{\mathrm{gge}},\left(\mathrm{HDL}_{3 \mathrm{cl}}\right)_{\mathrm{gge}}$, and $\left(\mathrm{HDL}_{3 \mathrm{c} 2}\right)_{\mathrm{gge}}$, respectively. $\mathrm{CB}$ contains a valley in the $\left(\mathrm{HDL}_{3 \mathrm{a}}\right)_{\mathrm{gge}}$ region (4) where normally there is a major peak in adult plasma (25).

Statistical analysis. Mean differences in relative peak height between infants with different gradient gel electrophoresis patterns in each HDL region were assessed using analysis of variance (26). For multiple comparisons, significance values were adjusted using the Bonferioni inequality (26). TC, TG, and HDL-C means by group and gradient gel electrophoresis patterns were compared using the same method. Because the distributions of these variables were skewed, natural $\log$ transformations were performed for the statistical tests. Reported $p$ values are based on these transformed values, however, the means and SDs reported are not transformed, so that they are clinically meaningful. Frequency distributions of gradient gel electrophoresis patterns were also compared using a $\chi^{2}$ test (27).

\section{RESULTS}

The mean TG and TC values for the $880 \mathrm{CB}$ plasmas were $41.5 \pm 15.5$ and $68.2 \pm 17.5 \mathrm{mg} / \mathrm{dl}$, respectively. The range for both measurements was large: 11-192 mg/dl for TG and 25$150 \mathrm{mg} / \mathrm{dl}$ for cholesterol. Of these samples, $5 \% \mathrm{had}$ TC values above $100 \mathrm{mg} / \mathrm{dl}$ while $1 \%$ had TG values above $100 \mathrm{mg} / \mathrm{dl}$. Only $0.5 \%$ of the samples had both elevated cholesterol and TG. These cholesterol and TG distributions are similar to those previously reported $(5,7,10,28-34)$.

The 154 samples for whom gge was performed were grouped according to the following criteria: Group I: infants with TG and TC levels below $100 \mathrm{mg} / \mathrm{dl}$, Apgar scores greater than 8, gestational age greater than $37 \mathrm{wk}$, appropriate weight for gestational age, and no pre- or perinatal complications. This group was considered the control group. Group II: term infants with gestational age greater than $37 \mathrm{wk}$, pre- or perinatal complications and/or TG and/or TC values above $100 \mathrm{mg} / \mathrm{dl}$. Group III: premature infants with gestational age $<37 \mathrm{wk}$, regardless of plasma lipid levels.

Gradient polyacrylamide gel electrophoresis of the 154 cord plasmas revealed that at least three distinct patterns are recognizable; representative scans of these patterns are shown in Figure 2. The first pattern (Fig. $2 A$ ) is distinguished by a prominent double peak in the $\left(\mathrm{HDL}_{2 \mathrm{a}}\right)_{\mathrm{gge}}$ region and a pronounced peak in the $\left(\mathrm{HDL}_{3 \mathrm{~b}}\right)_{\mathrm{gge}}$ region. Minor peaks or shoulders are seen in the $\left(\mathrm{HDL}_{2 \mathrm{~b}}\right)_{\mathrm{gge}}$ and $\left(\mathrm{HDL}_{3 \mathrm{c}}\right)_{\mathrm{gge}}$ regions and a valley is present in the $\left(\mathrm{HDL}_{3 \mathrm{a}}\right)_{\mathrm{gge}}$ region. Although not shown in Figure 2, the shoulder in the (HDL $\left.{ }_{3 c}\right)_{\text {gge }}$ region frequently resolves into two small components. We have termed this pattern the normal (gge) pattern and it is similar to that previously described for pooled normal $\mathrm{CB}$ samples (4). The second pattern is shown in Figure $2 B$ and contains a major peak in the $\left(\mathrm{HDL}_{2 \mathrm{~b}}\right)_{\mathrm{gge}}$ region rather than the shoulder seen in the normal pattern. The double peak is still visible in $\left(\mathrm{HDL}_{2 \mathrm{a}}\right)_{\mathrm{gge}}$ but this region and the $\left(\mathrm{HDL}_{3 \mathrm{~b}}\right)_{\mathrm{gge}}$ and $\left(\mathrm{HDL}_{3 \mathrm{c}}\right)_{\mathrm{gge}}$ regions are less pronounced than in the normal (gge) pattern. We have termed this the $2 \mathrm{~b}$ (gge) pattern. The third pattern, as demonstrated by the two scans (solid and broken line) in Figure $2 C$, is characterized by a paucity of material in the $\left(\mathrm{HDL}_{2 \mathrm{~b}}\right)_{\mathrm{gge}}$ region and a single peak in the $\left(\mathrm{HDL}_{2 \mathrm{a}}\right)$ region, the $\left(\mathrm{HDL}_{2 \mathrm{a} 2}\right)$ peak. The most prominent feature of this pattern is the relative increase in the $\left(\mathrm{HDL}_{3 \mathrm{~b}}\right)_{\mathrm{gge}}$ region (solid line) or the simultaneous increase in both $\left(\mathrm{HDL}_{3 \mathrm{~b}}\right)_{\mathrm{gge}}$ and $\left(\mathrm{HDL}_{3 \mathrm{c}}\right)_{\mathrm{gge}}$, indicated by the broken line, as compared with the normal pattern. 
The pattern represented by both these scans is termed the $3 \mathrm{~b}$ (gge) pattern.

Table 1 summarizes the mean values of the relative optical

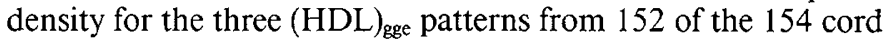
plasmas. One gradient gel pattern did not fit into any of the categories and one had a poor baseline; both were excluded from the analysis. Of the total scans, $64 \%$ had the normal (gge) pattern while 26 and $10 \%$ had $2 \mathrm{~b}$ (gge) and $3 \mathrm{~b}$ (gge) patterns, respectively. The mean relative optical density distribution for each of the patterns reflects the particle distribution seen in the representative scans shown in Figure 2. In the normal (gge) pattern, approximately $50 \%$ of the HDL material is in the $\left(\mathrm{HDL}_{2 \mathrm{a}}\right)_{\mathrm{gge}}$ region as a double peak. About $20-25 \%$ of the HDL is in the $\left(\mathrm{HDL}_{3 \mathrm{~b}}\right)_{\mathrm{gge}}$ region and the remaining $25 \%$ is distributed between very large and very small particles. A major difference in the $2 \mathrm{~b}$ (gge) pattern is a shift of $\mathrm{HDL}$ into the larger-sized $\left(\mathrm{HDL}_{2 \mathrm{~b}}\right)_{\mathrm{gge}}$ region at the expense of the smaller sized $\left(\mathrm{HDL}_{3 \mathrm{c}}\right)_{\mathrm{gge}}$ components

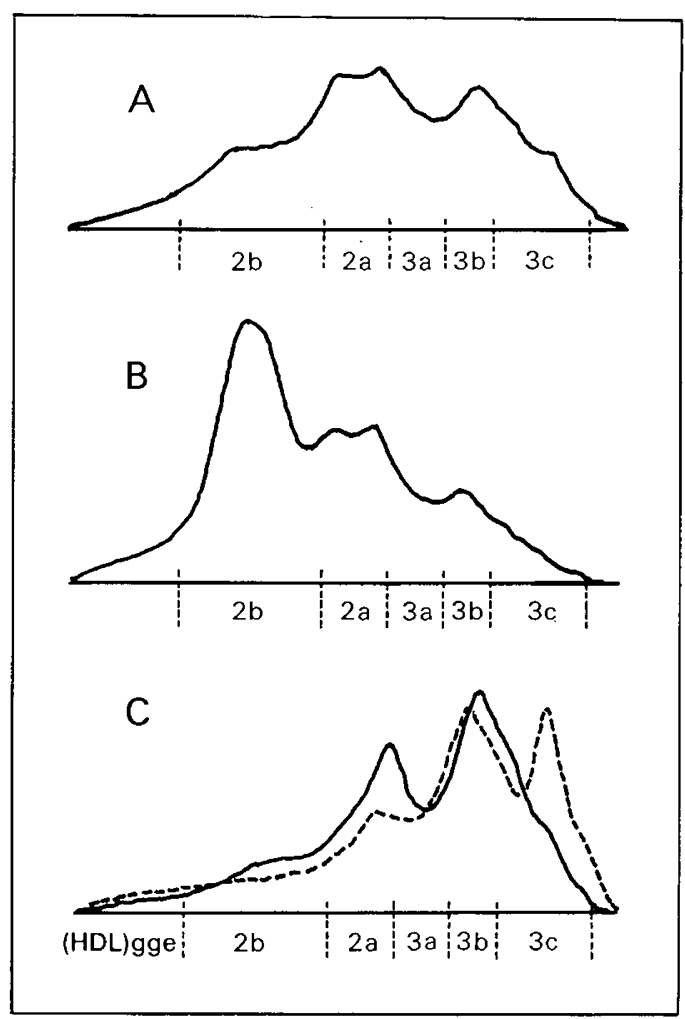

Fig. 2. Representative scans of the three types of gradient gel patterns noted in cord blood. $A$, normal (gge) pattern. $B, 2 \mathrm{~b}$ (gge) pattern. This is characterized by a pronounced increase in the $\left(\mathrm{HDL}_{2 b}\right)_{\mathrm{gge}}$ region and an elevation of cord blood cholesterol. $C, 3 \mathrm{~b}$ (gge) pattern. Two different forms of the pattern are noted: the solid line with a major peak in $\left(\mathrm{HDL}_{3 \mathrm{~b}}\right)_{\mathrm{gge}}$ and a shoulder in $\left(\mathrm{HDL}_{3 \mathrm{c}}\right)_{\mathrm{gge}}$; and the broken line with prominent peaks in both the $\left(\mathrm{HDL}_{3 \mathrm{~b}}\right)_{\mathrm{gge}}$ and $\left(\mathrm{HDL}_{3 \mathrm{c}}\right)_{\mathrm{gge}}$ regions. This pattern is associated with elevated TG levels. as compared to the normal (gge) pattern. The peak in the $\left(\mathrm{HDL}_{2 \mathrm{~b}}\right)_{\mathrm{gge}}$ region is double the average intensity of that of the normal pattern (see Table 1). Within the $\left(\mathrm{HDL}_{2 \mathrm{a}}\right)_{\mathrm{gge}}$ region, the $\left(\mathrm{HDL}_{2 \mathrm{al}}\right)_{\mathrm{gge}}$ component, which has a mean particle diameter of $9.3 \pm 0.1 \mathrm{~nm}$, has slightly more material; coincidentally, the $\left(\mathrm{HDL}_{2 \mathrm{a} 2}\right)_{\mathrm{gge}}$ component with a mean particle diameter of $8.8 \pm$ $0.1 \mathrm{~nm}$ is decreased. These changes are small but statistically significant as seen in Table 1 . In the $3 b$ (gge) pattern, the HDL are shifted toward the smaller particle sizes. There is almost a complete absence of larger, less dense particles in the $\left(\mathrm{HDL}_{2 \mathrm{~b}}\right)_{\mathrm{gge}}$ region and in the $\left(\mathrm{HDL}_{2 \mathrm{al}}\right)_{\mathrm{gge}}$ peak (Table 1). Although the $\left(\mathrm{HDL}_{2 \mathrm{a}}\right)_{\mathrm{gge}}$ peak is still apparent, its intensity is lower in comparison with the normal (gge) pattern but statistically not different from the $2 \mathrm{~b}$ (gge) pattern (Table 1 ). The $3 \mathrm{~b}$ (gge) pattern has detectable material in the $\left(\mathrm{HDL}_{3 \mathrm{a}}\right)_{\mathrm{gge}}$ region, probably reflecting some spill over material from the extremely prominent $\left(\mathrm{HDL}_{3 \mathrm{~b}}\right)_{\mathrm{gge}}$ region. The average intensity of the $\left(\mathrm{HDL}_{3 \mathrm{~b}}\right)_{\mathrm{gge}}$ peak is double that of the normal (gge) pattern. The $\left(\mathrm{HDL}_{3 \mathrm{cl}}\right)_{\mathrm{gge}}$ peak, which has a mean particle diameter of $7.6 \pm 0.1 \mathrm{~nm}$, is slightly increased but is not statistically significantly different from the normal (gge) pattern. The $\left(\mathrm{HDL}_{3 \mathrm{c} 2}\right)_{\mathrm{gge}}$ peak (mean particle diameter of $7.4 \pm 0.1 \mathrm{~nm}$ ), however, is significantly increased, reflecting the presence of the sharp peak in certain patterns as shown in the broken line in Figure $2 C$. These data support the premise that three distinct HDL subclasses exist in CB.

Table 2 shows the frequency distribution of the gradient gel patterns in the group I, II, and III cord blood samples. The normal (gge) pattern is clearly the predominant pattern $(89 \%)$ in group I (control) infants and accounts for 50 and $43 \%$ of the patterns in group II and III infants, respectively. The $2 \mathrm{~b}$ (gge) pattern appears most frequently $(49 \%)$ in the group III (premature) infants and also accounts for a considerable number $(30 \%)$ of group II infants. The $3 \mathrm{~b}$ (gge) pattern is observed less frequently ( $10 \%$ of all patterns) but is most frequent among the group II infants. The difference in pattern distribution between group I infants and the other two groups is statistically significant $\left(\chi^{2}=\right.$ $33.03, p \leq 0.0001$ ).

Table 3 shows the relationships between gradient gel patterns and plasma lipid values of the three infant groups. The mean concentrations for TG, TC, and HDL-C in infants with the normal (gge) pattern were within the limits of normal lipid values for newborn infants and averages ranged from $30-43,62-85$,

Table 2. Frequency distribution of gradient gel electrophoretic patterns in group I, II, and III infants

\begin{tabular}{|c|c|c|c|c|}
\hline & $\begin{array}{c}\text { Group } \\
\text { I }\end{array}$ & $\begin{array}{l}\text { Group } \\
\text { II }\end{array}$ & $\begin{array}{l}\text { Group } \\
\text { III }\end{array}$ & Total \\
\hline Gradient gel pattern & $n(\%)$ & $n(\%)$ & $n(\%)$ & $n(\%)$ \\
\hline Normal(gge) pattern & $55(89)$ & $28(50)$ & $15(43)$ & $98(64)$ \\
\hline $2 \mathrm{~b}$ (gge) pattern & $5(8)$ & $17(30)$ & $17(49)$ & $39(26)$ \\
\hline $3 \mathrm{~b}$ (gge) pattern & $2(3)$ & $11(20)$ & $3(9)$ & $16(10)$ \\
\hline Total & 62 & 56 & 35 & 153 \\
\hline
\end{tabular}

Table 1. Mean ( $\pm S D$ ) relative optical density of HDL subpopulations according to gradient gel pattern and peak location within (HDL)gge distribution

\begin{tabular}{|c|c|c|c|c|c|c|c|c|}
\hline \multirow[b]{3}{*}{ GGE pattern } & \multirow[b]{3}{*}{$n$} & \multicolumn{7}{|c|}{ Location of peak in HDL scan } \\
\hline & & \multirow[t]{2}{*}{$2 b$} & \multicolumn{2}{|c|}{$2 \mathrm{a}$} & \multirow[t]{2}{*}{$3 a$} & \multirow[t]{2}{*}{$3 \mathrm{~b}$} & \multicolumn{2}{|c|}{$3 c$} \\
\hline & & & Peak 1 & Peak 2 & & & Peak 1 & Peak 2 \\
\hline Normal pattern & $98(64 \%)$ & $16 \pm 5$ & $20 \pm 8$ & $25 \pm 5$ & 0 & $22 \pm 6$ & $9 \pm 9$ & $9 \pm 7$ \\
\hline $2 b($ gge $)$ pattern & $39(26 \%)$ & $30 \pm 6^{*}$ & $23 \pm 5 \dagger$ & $20 \pm 7^{*}$ & $2 \pm 6$ & $15 \pm 4^{*}$ & $6 \pm 6$ & $5 \pm 6 \dagger$ \\
\hline $3 b$ (gge) pattern & $15(10 \%)$ & $4 \pm 5^{*,} \S$ & $0^{*,} \S$ & $19 \pm 11^{*}$ & $5 \pm 12^{*} \|$ & $44 \pm 18^{*}, \S$ & $13 \pm 15 \|$ & $16 \pm 16^{*}, \S$ \\
\hline
\end{tabular}

$* p<0.01 ; \dagger p<0.05$ for comparison of means with the normal pattern samples.

$\S p<0.01 ; \| p<0.05$ for comparison of means with the $2 \mathrm{~b}$ (gge) pattern samples. 
Table 3. Mean values of $T G, T C$, and $H D L-C( \pm S D)$ by gradient gel pattern and infant group

\begin{tabular}{|c|c|c|c|c|c|c|c|c|c|}
\hline \multirow{2}{*}{$\begin{array}{c}\text { GGE } \\
\text { pattern }\end{array}$} & \multicolumn{3}{|c|}{ TG* } & \multicolumn{3}{|c|}{$\mathrm{TC} \dagger$} & \multicolumn{3}{|c|}{ HDL-C $\dagger$} \\
\hline & Group I & Group II & Group III & Group I & Group II & Group III & Group I & Group II & Group III \\
\hline Normal & $34.2 \pm 11.9$ & $43.4 \pm 15.5$ & $30.1 \pm 11.3$ & $62.5 \pm 11.6$ & $80.1 \pm 20.8$ & $85.4 \pm 26.5$ & $33.6 \pm 7.5$ & $40.8 \pm 12.6$ & $37.3 \pm 10.9$ \\
\hline $2 b($ gge $)$ & $27.9 \pm 1.9$ & $39.7 \pm 13.2$ & $32.4 \pm 8.2$ & $84.1 \pm 9.1$ & $101.8 \pm 19.6$ & $97.0 \pm 24.3$ & $51.5 \pm 6.0$ & $56.1 \pm 13.9$ & $49.1 \pm 11.1$ \\
\hline $3 b$ (gge) & $87.8 \pm 5.7$ & $86.5 \pm 42.7$ & $78.3 \pm 5.5$ & $72.5 \pm 4.1$ & $56.8 \pm 24.2$ & $75.3 \pm 27.0$ & $30.0 \pm 8.1$ & $19.5 \pm 6.8$ & $22.8 \pm 19.7$ \\
\hline
\end{tabular}

${ }^{*} p<0.01$, for comparison of means between $3 \mathrm{~b}$ (gge) pattern with normal and $2 \mathrm{~b}$ (gge) patterns based on natural log transformed variables.

$\dagger p<0.01$, for comparison of means between all three patterns based on natural log transformed variables.

and $34-41 \mathrm{mg} / \mathrm{dl}$, respectively, in the three groups. Compared with the normal (gge) pattern, infants with the $2 \mathrm{~b}$ (gge) pattern have significantly higher TC (mean $84-102 \mathrm{mg} / \mathrm{dl}$ ) and HDL-C (mean 49-56 mg/dl) but normal TG levels. The TC levels of the infants with the $3 \mathrm{~b}$ (gge) pattern were somewhat lower than the control group, but TG levels (mean 78-88 mg/dl) were significantly elevated. Infants with this pattern had statistically significantly lower HDL-C (mean $20-30 \mathrm{mg} / \mathrm{dl}$ ) levels.

These data strongly suggest that elevated $\mathrm{CB}$ cholesterol is associated with the appearance of the $2 \mathrm{~b}$ (gge) pattern, while elevated TG is associated with the $3 \mathrm{~b}$ (gge) pattern, irrespective of the infant group.

\section{DISCUSSION}

Several investigators have shown that prenatal and perinatal complications can influence CB lipid levels (12-20). It is well known that prematurity (gestational age less than $37 \mathrm{wk}$ ) is associated with elevated TC and low TG $(12,14,17-19,21)$ and that TC is elevated in infants of diabetic mothers $(19,35,36)$. In addition, placental insufficiency, low Apgar, nuchal cord, and meconium staining are associated with elevated CB TG $(13,22)$. It has not been reported whether the change in lipid levels is also accompanied by a change of the subclass distribution of neonatal HDL, and this question was examined in the present report.

Davis et al. (4), using nondenaturing gradient gel electrophoresis, demonstrated that pooled and individual $\mathrm{CB}$ samples from full-term normal infants had a very characteristic size distribution profile which was different from that of adults. They observed that cord blood HDL possessed larger-sized particles in the $\left(\mathrm{HDL}_{2 \mathrm{~b}}\right)_{\mathrm{gge}}$ region, a double peak in the $\left(\mathrm{HDL}_{2 \mathrm{a}}\right)_{\mathrm{gge}}$ region, and smaller $\mathrm{HDL}$ in the $\left(\mathrm{HDL}_{3 \mathrm{c}}\right)_{\mathrm{gge}}$ region; additionally, there was little or no HDL in the $\left(\mathrm{HDL}_{3 \mathrm{a}}\right)_{\mathrm{gge}}$ region. Our present results with infants having the "normal" (gge) pattern show three prominent peaks of almost equal intensity: two within the $\left(\mathrm{HDL}_{2 \mathrm{a}}\right)_{\mathrm{gge}}$ region with estimated particle diameters of $9.3 \pm 1.3$ and $8.8 \pm$ $1.2 \mathrm{~nm}$ and one within the $\left(\mathrm{HDL}_{3 \mathrm{~b}}\right)_{\mathrm{gge}}$ region with a particle diameter of $7.9 \pm 0.9 \mathrm{~nm}$. This pattern agrees well with that previously described by Davis et al. (4). Of our "control" group $89 \%$, i.e. normal term infants with $\mathrm{TG}$ and $\mathrm{TC}$ concentrations below $100 \mathrm{mg} / \mathrm{dl}$, had the normal (gge) pattern. Of the 880 original cord blood samples, the TG and TC distributions of 131 consecutive births of full-term infants with normal Apgar scores and no pre- or perinatal complications were analyzed retrospectively. In this sample, the 95 th percentiles were $65 \mathrm{mg} / \mathrm{dl}$ for TG and $85 \mathrm{mg} / \mathrm{dl}$ for TC. If these cutoff points are used, the percentage of group I infants with a normal (gge) pattern increases to $96 \%$ since seven samples would be excluded from the original control group (group I) of 62 infants. This high degree of uniformity suggests that healthy full-term infants with normal lipid levels have a predictable HDL subclass distribution. This consistency of size distribution probably reflects the constancy of the milieu of the fetus in utero where diet and environmental factors have little impact.

The $2 \mathrm{~b}$ (gge) pattern with its increased $\left(\mathrm{HDL}_{2 \mathrm{~b}}\right)_{\mathrm{gge}}$ and $\left(\mathrm{HDL}_{2 \mathrm{a} 1}\right)_{\mathrm{gge}}$ peaks is associated with $\mathrm{CB}$ cholesterol levels greater than $85 \mathrm{mg} / \mathrm{dl}$. This pattern is also associated with increased HDL-C levels. Not surprisingly, the $2 \mathrm{~b}$ (gge) pattern is seen most frequently in group III infants (approximately $50 \%$ of the group), since prematurity has been described by several investigators to be associated with elevated cholesterol levels $(12,14,17-19,21)$.
The parallel increase in the $\left(\mathrm{HDL}_{2 \mathrm{~b}}\right)_{\mathrm{gge}}$ and $\left(\mathrm{HDL}_{2 \mathrm{a} 1}\right)_{\mathrm{gge}}$ peaks in this pattern, together with a decrease in intensity of peaks which correspond to smaller, more dense particles, suggests a metabolic transformation from smaller to larger particles. Although the metabolic origin of HDL subclasses is not fully understood, it has been postulated that lipases, lecithin:cholesterol acyltransferase, and lipid transfer protein have functional roles in determining the overall HDL pattern in adults. Lipoprotein lipase, by hydrolysis of TG-rich particles, generates surface remnant components (including phospholipid and cholesterol) which are taken up by HDL thus forming larger particles (37-39). Phospholipid and free cholesterol are substrates for lecithin: cholesterol acyltransferase, which generates cholesteryl ester that forms the core of larger, less dense HDL (40). It is thought that cholesteryl ester in the large HDL is exchanged for TG in very low-density lipoproteins through the action of the lipid transfer protein (4143). The HDL TG is subsequently hydrolyzed by hepatic lipase which in effect transforms the large HDL particle to a smaller, more dense one $(44,45)$. One would expect that if all these factors are functional in $\mathrm{CB}$, the $\left.\mathrm{HDL}_{2 \mathrm{~b}}\right)_{\text {gge }}$ peak would be reduced in intensity. Since this peak in infants with the $2 \mathrm{~b}$ (gge) pattern is approximately twice that of the normal (gge) pattern, an impairment in the transformation of large HDL to small HDL is suggested. CB lecithin:cholesterol acyltransferase activity, although low (46-48), functions normally since the cholesteryl ester to free cholesterol ratio is similar to adults (49). Lipoprotein lipase activity in the newborn is also similar to that of adults while hepatic lipase activity is 2- to 3-fold higher in newborn infants (50). Although speculative, the unusual elevation of $\left(\mathrm{HDL}_{2 \mathrm{~b}}\right)_{\mathrm{gge}}$ may be the result of very low-density lipoprotein levels in cord blood. Deficiency of very low-density lipoprotein, the preferred donor of TG and acceptor of cholesteryl ester in the TG-for-cholesteryl-ester exhange process, could limit interconversion of large particles to small ones. The preceding hypothesis assumes that the level of lipid transfer protein in cord plasma is normal; however, at present such data are not available.

In the present study, we found that elevation of CB TG $(>65$ $\mathrm{mg} / \mathrm{dl}$ ) was associated with a distinct $3 \mathrm{~b}$ (gge) pattern which shows a paucity of larger, less dense HDL particles. This pattern is also associated with a significant decrease in HDL-C levels. The $3 \mathrm{~b}$ (gge) pattern is most frequently encountered in term infants with pre- and perinatal complications, conditions associated with elevated CB TG levels. Recent reports on adult subjects with hypertriglyceridemia have shown, upon gradient gel electrophoresis, that elevated TG is associated with a pronounced increase in the $\left(\mathrm{HDL}_{3 \mathrm{~b}}\right)_{\mathrm{gge}}$ region $(25,51)$. The study of Chang et al. (51) provides evidence that the shift from larger particles to smaller ones in adults is progressive as plasma TG levels increase. At plasma TG levels $>330 \mathrm{mg} / \mathrm{dl}$ they noted that the predominant peak has a diameter of $7.8 \mathrm{~nm}$, corresponding to the $\left(\mathrm{HDL}_{3 \mathrm{~b}}\right)_{\mathrm{gge}}$ peak in $\mathrm{CB}$. Although the elevation of TG in CB is far less in absolute concentrations than that of adult hypertriglyceridemic plasma, the response of HDL size distribution is similar: CB plasma with TG levels above $65 \mathrm{mg} / \mathrm{dl}$ is associated with a decrease in larger, less dense HDL, and an increase in smaller, more dense HDL. The metabolic mechanism for depletion of $\mathrm{HDL}_{2}$ particles and coincident increase in smaller $\mathrm{HDL}_{3}$ particles in hypertriglyceridemia are not fully understood. It is interesting, however, that in adults an inverse relationship has been noted between hepatic lipase activity and levels of $\mathrm{HDL}_{2}(52,53)$. 
Simultaneous elevation of CB TG and cholesterol occurs very infrequently. In the present series, two infants were in this category. The first had TG and cholesterol levels of 139 and 93 $\mathrm{mg} / \mathrm{dl}$, respectively, while the second had values of 72 and 106 $\mathrm{mg} / \mathrm{dl}$, respectively. The former infant had low HDL-C $(28 \mathrm{mg} /$ dl) while the latter had slightly elevated HDL-C (46 mg/dl). In both cases, the HDL exhibited the $3 \mathrm{~b}$ (gge) pattern. Apparently, high cholesterol levels and even higher HDL-C levels do not allow the metabolic formation of large, less dense HDL particles if TG levels are concurrently elevated. Thus, where both TG and cholesterol are elevated, it is suggested that TG is the major determinant of fetal HDL subclass distribution.

Our study demonstrates that cord blood lipid levels are the most important factors influencing HDL subclass distribution. High TC is related to an increase of particles in the $\left(\mathrm{HDL}_{2 \mathrm{~b}}\right)_{\mathrm{gge}}$ region. High TG levels are associated with a decrease in the amount of particles in the $\left(\mathrm{HDL}_{2 \mathrm{~b}+2 \mathrm{a}}\right)_{\mathrm{gge}}$ region and with a concomitant increase of particles in the $\left(\mathrm{HDL}_{3 \mathrm{~b}}\right)_{\mathrm{gge}}$ region.

Acknowledgments. The authors thank Janet Selmek-Halsey and Robert Nordhausen for their excellent technical assistance and Mary Lou Olbrich and Linda Abe for their preparation of the manuscript. Cord blood samples were kindly provided by Dr. Bert Lubin, Children's Hospital, Oakland, CA, through his project on hemoglobinopathies in neonates.

\section{REFERENCES}

1. Miller GJ, Miller NF 1975 Plasma-high density lipoprotein concentration and development of ischemic heart disease. Lancet 1:16-20

2. Castelli W, Doyle JT, Gordon T, Hames CG, Hjortland MC, Hulley SB, Kagan A, Zukel WJ 1977 HDL cholesterol and other lipids in coronary heart disease: the Cooperative Lipoprotein Phenotyping Study. Circulation 55:767-772

3. Castelli W, Castelli WP, Hjortland MC, Kannel WB, Dawber TR 1977 High density lipoprotein as a protective factor against coronary heart disease: the Framingham Study. Am J Med 62:707-714

4. Davis PA, Forte TM, Nichols AV, Blum CB 1983 Umbilical cord blood lipoproteins: isolation and characterization of high density lipoproteins. Arteriosclerosis 3:357-365

5. Dyerberg J, Hjorne N, Nymand G, Olsen JS 1974 Reference values for cord blood lipid and lipoprotein concentrations. Acta Paediatr Scand 63:431-436

6. Ginsburg BE, Zetterstrom R 1977 High density lipoprotein concentrations in newborn infants. Acta Paediatr Scand 66:39-41

7. Hardell LI 1981 Serum lipids and lipoproteins at birth based on a study of 2815 newborn infants, I. Concentrations and distributions of triglyceride and cholesterol. Acta Paediatr Scand [Suppl] 285:5-10

8. Strobl W, Widhalm K, Kostner G, Pollak A 1983 Serum apolipoproteins and lipoprotein (a) during the first week of life. Acta Paediatr Scand 72:505-509

9. Van Biervliet JP, Vercaemst R, De Keersgheter W, Vinaimont N, Caster H, Rosseneu M 1980 Evolution of lipoprotein patterns in newborns. Acta Paediatr Scand 69:593-596

10. Winkler L, Schlag B, Goetze E 1977 Concentration and composition of the lipoprotein classes in human umbilical cord serum. Clin Chim Acta 76:187191

11. Blanche PJ, Gong EL, Forte TM, Nichols AV 1981 Characterization of human high density lipoproteins by gradient gel electrophoresis. Biochim Biophys Acta 665:408-419

12. Andersen GE, Friis-Hansen B 1978 Hypercholesterolemia in the newborn: occurrence after antepartum treatment with betamethasone-phenobarbitalritodrine for the prevention of the respiratory distress syndrome. Pediatrics 62:8-12

13. Andersen GE, Friis-Hansen B 1976 Neonatal hypertriglyceridemia. Acta Paediatr Scand 65:369-374

14. Christensen NC 1977 Concentrations of triglycerides, free fatty acids, and glycerol in cord blood of newborn infants with a birth weight of $\leqslant 2700$ grams. Acta Paediatr Scand 66:43-48

15. Cress HR, Shaher RM, Laffin R, Karpowicz K 1977 Cord blood hyperlipoproteinemia and perinatal stress. Pediatr Res 11:19-23

16. Fosbrooke AS, Wharton BA 1973 Plasma lipids in umbilical cord blood from infants of normal and low birth weight. Biol Neonate 23:330-338

17. Ginsburg BE, Zetterstrom R 1980 Serum cholesterol concentrations in newborn infants with gestational ages of $28-42$ weeks. Acta Paediatr Scand 69:587-592

18. Hardell LI 1981 Serum lipids and lipoproteins at birth based on a study of 2815 newborn infants: II, relations between materno-foetal factors and the concentrations of triglycerides and cholesterol. Acta Paediatr Scand Supply 285:11-20.

19. Lane DM, McConathy WJ 1983 Factors affecting the lipid and apolipoprotein levels of cord sera. Pediatr Res 17:83-91

20. Martinsen K, Ehnholm C, Huttunen JK, Tervila L, Kostiainen E 1981 Intrapartum stress lowers the concentration of high density lipoprotein cholesterol in cord plasma. Eur J Clin Invest 11:351-354
21. Parker CR Jr, Simpson ER, Bilheimer DW, Leveno K, Carr BR, MacDonald PC 1980 Inverse relation between low-density lipoprotein-cholesterol and dehydroisoandrosterone sulfate in human fetal plasma. Science 208:512514

22. Tsang RC, Glueck CJ, Evans G, Steiner PM 1974 Cord blood hypertriglyceridemia. Am J Dis Child 127:78-82

23. Steele BW, Koehler DF, Azar MM, Blaszkowski TP, Kuba Kanta, Dempsey ME 1976 Enzymatic determinations of cholesterol in high-density lipoprotein fractions prepared by a precipitation technique. Clin Chem 22:98-101

24. Lindgren FT, Jensen LC, Hatch FT 1972 The isolation and quantitative analysis of serum lipoproteins. In: Nelson GJ (ed) Blood Lipids and Lipoproteins. John Wiley-Interscience, New York, pp 181-274

25. Nichols AV, Blanche PJ, Gong EL 1983 Gradient gel electrophoresis of human plasma high density lipoproteins. In: Lewis LA (ed) CRC Handbook of Electrophoresis, Vol III. CRC Press, Inc., Boca Raton, FL, pp 29-47

26. Dunn OJ, Clark VA 1974 Applied Statistics: Analysis of Variance and Regression. John Wiley \& Sons, New York, pp 62-83, 132-144

27. Dixon WJ, Massey FJ 1969 Introduction to Statistical Analysis, 3rd ed. McGraw-Hill, New York, pp 237-243

28. Anderson GE, Friis-Hansen B 1976 Neonatal diagnosis of familial type II hyperlipoproteinemia Pediatrics 57:214-220

29. Boulton TJC, Craig IH, Hill G 1979 Screening of cord blood low-densitylipoprotein cholesterol in the diagnosis of familial hypercholesterolemia: a study of 2000 infants. Acta Paediatr Scand 68:363-370

30. Devi CS, Sastry BSV, Mohan Kumar Y, Raju GRK, Suryaprabha K 1982 Concentration of triglyceride and cholesterol in lipoprotein fractions in maternal and cord blood samples. Clin Chim Acta 123:169-173

31. Frerichs RR, Srinivasan Sr, Webber LS, Berenson GS 1978 Serum cholesterol and triglyceride levels in children from a biracial community: the Bogalusa Heart Study. Pediatr Res 12:858-863

32. Glueck CJ, Heckman F, Schoenfeld M, Steiner P, Pearce W 1971 Neonatal familial type II hyperlipoproteinemia: cord blood cholesterol in 1800 births. Metabolisms 20:597-609

33. Kwiterovich PO Jr, Levy RI, Frederickson DS 1973 Neonatal diagnosis of familial type II hyperlipoproteinemia. Lancet 1:118-121

34. Mishkel MA 1974 Neonatal plasma lipids as measured in cord blood. Can Med Assoc J 111:775-780

35. Mortimer JG 1964 Cord blood lipids of normal infants and infants of diabetic mothers. Arch Dis Child 39:342-344

36. Pantelakis SN, Cameron AH, Davidson S, Dunn PM, Fosbrooke AS, Lloyd JK, Malins JM, Wolff $\mathrm{OH} 1964$ The diabetic pregnancy: a study of serum lipids in maternal and umbilical cord blood and of uterine and placental vasculature. Arch Dis Child 39:334-341

37. Patsch JR, Gotto AM Jr, Olivecrona T, Eisenberg S 1978 Formation of high density lipoprotein ${ }_{2}$-like particles during lipolysis of very low density lipoproteins in vitro. Proc Natl Acad Sci USA 75:4519-4523

38. Forte TM, Krauss RM, Lindgren FT, Nichols AV 1979 Changes in plasma lipoprotein distribution and formation of two unusual particles after heparininduced lipolysis in hypertriglyceridemic subjects. Proc Natl Acad Sci USA 76:5934-5938

39. Tall AR, Small DM 1980 Body cholesterol removal: role of plasma highdensity lipoproteins. Adv Lipid Res 17:1-51

40. Glomset JA, Norum KR 1973 The metabolic role of lecithin:cholesterol acyltransferase: perspectives form pathology. Adv Lipid Res 11:1-65

41. Nichols AV, Smith L 1965 Effect of very-low density lipoproteins on lipid transfer in incubated serum. J Lipid Res 6:206-210

42. Marcel YL, Vezina C, Teng B, Sniderman A 1980 Transfer of cholesterol esters between human high density lipoproteins and triglyceride-rich lipoproteins controlled by a plasma protein factor. Atherosclerosis 35:127-133

43. Hopkins GJ, Barter PJ 1980 Transfers of esterified cholesterol and triglyceride between high density and very low density lipoproteins: in vitro studies of rabbits and humans. Metabolism 29:546-550

44. Jansen H, Van Tol A, Hulsmann WC 1980 On the metabolic function of heparin-releasable liver lipase. Biochem Biophys Res Commun 92:53-59

45. Van Tol A, Van Gent T, Jansen H 1980 Degradation of high density lipoprotein by heparin-releasable liver lipase. Biochem Biophys Res Commun 94:101108

46. Lacko AG, Rutenberg HL, Soloff LA 1972 On the rate of cholesterol esterification in cord blood serum. Lipids 7:426-429

47. Klimov AN, Nikiforova AA, Chistyakova AM, Magracheva EY, Anderson DW 1978 Lecithin:cholesterol acyltransferase deficiency in the blood plasma of newborn. Artery 4:9-27

48. Dobiasova M, Stozicky F, Kopecka J 1984 Lecithin:cholesterol acyltransferase activity in children in the early neonatal period. Biol Neonate 45;165-168

49. Pocovi M, Ordovas JM, Grande F 1983 Lecithin:cholesterol acyltransferase, lipids and lipoproteins in maternal and umbilical cord plasma. Artery 11:264-272

50. Rovamo L, Taskinen M-R, Kuusi T, Nikkila EA, Ehnholm C, Raivio KO 1984 Postheparin plasma lipase activities and plasma lipoproteins in newborn infants. Pediatr Res 18:642-647

51. Chang LBF, Hopkins GJ, Barter PJ 1985 Particle size distribution of high density lipoproteins as a function of plasma triglyceride concentration in human subjects. Atherosclerosis 56:61-70

52. Kuusi T, Saarinen P, Nikkila EA 1980 Evidence for the role of hepatic endothelial lipase in the metabolism of plasma high density lipoprotein ${ }_{2}$ in man. Atherosclerosis 36:589-593

53. Breckenridge WC, Little JA, Alaupovic P, Wang CS, Kuksis A, Kakis G, Lindgren F, Gardiner G 1982 Lipoprotein abnormalities associated with a familial deficiency of hepatic lipase. Atherosclerosis 45:161-179 